\title{
HARTA BERSAMA AKIBAT PERCERAIAN DALAM KHI dan UU NO. 1 TAHUN 1974
}

\section{Ridwan Jamal}

\section{ABSTRAK}

Tulisan ini adalah membahas tentang suatu analisis pembagian harta bersama akibat adanya perceraian. Dalam tulisan ini saya mencoba membandingkan pengaturan tentang harta bersama yang terdapat dalam KHI dan UU No. 1 Tahun 1974, yang mana kedua aturan ini memiliki kesamaan dalam penentuan harta bersama, hanya saja dalam UU No. 1 Tahun 1974 masalah harta bersama sifatnya lebih sederhana karena hanya dibahas 3 pasal saja yaitu pasal 35-37. Sedangkan dalam KHI masalah harta bersama lebih lengkap dengan menguraikannya dalam 13 pasal yaitu pasal 85-97. Kedua macam aturan ini sifatnya saling melengkapi satu sama lain.

Kata Kunci : Harta Bersama, KHI, UU No.1 Tahun 1974

\section{A. Pendahuluan}

Pernikahan merupakan ibadah dan Islam sendiri telah menganjurkan kepada orang-orang yang telah memilki kemampuan agar segera melangsungkan pernikahan agar terhindar dari perbuatan maksiat. Pernikahan yang merupakan suatu ikatan lahir bathin antara seorang pria dengan seorang wanita diharapkan dapat membentuk sebuah keluarga yang bahagia, sejahtera, kekal dan abadi berdasarkan atas Ketuhanan Yang Maha Esa.

Namun demikian, suatu pernikahan sering kali berakhir dengan suatu perceraian karena dianggap pernikahan tersebut sudah tidak dapat diprtahankan lagi. Perceraian merupakan salah satu sebab putusnya pernikahan, disamping karena adanya kematian dan atas putusan Pengadilan.

Pernikahan yang berakhir dengan suatu perceraian pasti akan membawa permasalahan baru, dimana salah satu pihak baik pihak suami maupun pihak isteri 
pasti akan mengajukan gugatan tentang harta bersama dalam penyelesaian perceraian. Harta bersama merupakan masalah yang sangat besar pengaruhnya dalam kehidupan suami isteri apabila terjadi perceraian, harta bersama sering kali muncul pada saat telah terjadi perceraian atau bahkan pada saat perceraian sedang berlangsung atau diproses di Pengadilan Agama.

Di Indonesia ketentuan umum mengenai harta bersama diatur dalam pasal 31 UU No.1 Tahun 1974 yang menjelaskan bahwa bila pernikahan putus karena perceraian maka harta bersama diatur menurut humnya masing-masing. ${ }^{1}$ Hal ini berarti bahwa gugatan harta bersama disandarkan pada hukum yang berlaku pada suatu daerah, artinya jika pada daerah tersebut menganut hukum adat maka penyelesaian harta bersama diselesaikan berdasarkan hukum adat. Bila ditelusuri lebih mendalam terhadap masyarakat hukum adat ternyata terdapat juga orangorang yang beragama Islam yang kurang memahami tentang pembagian harta secara Islam, padahal di Indonesia sudah ada suatu wadah yang dapat menyelesaikan harta bersama yaitu Pengadilan Agama. Segala harta benda yang diperoleh suami isteri selama mereka masih diikat dalam suatu ikatan pernikahan, maka harta tersebut dinamakan harta bersama.

Berdasarkan ketentuan di atas dapat diperoleh penjelasan bahwa terbentuknya harta bersama dalam pernikahan adalah sejak saat tanggal terjadinya pernikahan sampai ikatan pernikahan itu bubar, artinya pada saat terjadi pernikahan antara suami isteri terjadi kesatuan harta pada harta kekayaan yang pada akhirnya dapat dibagi secara adil antara suami isteri apabila telah terjadi perceraian.

Ynag menjadi masalah pokok yang akan dibahas dalam tulisan ini adalah bagaimana menangani masalah harta bersama apabila terjadi perceraian?

\section{B. Pembahasan}

\section{Pengertian, Dasar Hukum dan Ruang Lingkup Harta Bersama}

${ }^{1}$ Martadi, Jurnal Mimbar Hukum, No. 38 Mei-Juni Tahun IX 1998 dengan judul Analisis Yurisprudensi Tentang Harta Bersama ( Jakarta : Alhikmah dan Ditbampera, 1998 ) h. 48. 
Istilah harta bersama memiliki penyebutan yang berbeda-beda ditiap-tiap daerah. Misalnya di Kalimantan disebut dengan barang perpantangan, dan Minangkabau harta bersama dikenal dengan istilah harta suarang, di Sulawesi Selatan (Makassar dan Bugis) menggunakan istilah cakkara, di Jawa Tengah dan Jawa Timur lazim disebut dengan gono gini. ${ }^{2}$

Kemudian untuk pengertian dari harta bersama terdapat bermacam-macam penafsiran, diantaranya terdapat dalam Situs Asiamaya yang menulis bahwa gono gini is property acquired jointly, especially during marriage, and which is divided equally is event of divorce, ${ }^{3}$ artinya harta bersama atau gono gini adalah harta yang berhasil dikumpulkan secara berumah tangga sehingga menjadi hak berdua suami isteri.

Pengertian lain dikemukakan oleh Prof. Dr. K. Vandijk ${ }^{4}$ yang mengemukakan bahwa segala sesuatu yang diperoleh secara perkawinan adalah merupakan harta pencaharian yang lazim disebut sebagai harta serikat atau harta bersama. Hal ini berkaitan dengan Putusan Mahkamah Agung RI No. 02 $\mathrm{K} / \mathrm{Ag} / 1979^{5}$ yang menyebutkan bahwa harta yang diperoleh secara perkawinan adalah merupakan harta bersama (harta syarekat) antara suami isteri.

Kemudian dalam Kompilasi Hukum Islam yang berlaku dalam Pengadilan Agama, harta bersama disebut dengan istilah "harta kekayaan dalam perkawinan". Definisinya terdapat dalam pasal 1 huruf $\mathrm{f}$, dimana dijelaskan bahwa harta bersama adalah harta yang diperoleh baik sendiri-sendiri atau bersama suami isteri selama dalam ikatan perkawinan. Pada Kamus Besar Bahasa Indonesia harta bersama diidentikkan dengan gono gini atau gana gini yaitu harta yang berhasil

\footnotetext{
${ }^{2}$ R. Winjoyo Prodjodikoro, Hukum Perkawinan di Indonesia Cet. IX ; Jakarta : Sumur Bandung, 1991), h. III

${ }^{3}$ Lihat, http://www.aasiamaya.com/dictionary/ganagini.htm., diakses 14 Agustus 2004.

${ }^{4}$ Mr. A. Soehardi, Pengantar Hukum Adat (Cetk. III ; Bandung : Vornik on Hoeve, t.th), h. 39 .

${ }^{5}$ Mahkamah Agung RI Yurisprudensi Indonesia, Putusan-putusan Agama (Cet. I; Jakarta, : PT. Garuda Metropolitan Press, 1985) h. 21.
} 
dikumpulkan secara berumah tangga sehingga menjadi hak berdua diantara suami isteri. $^{6}$

Dalam hukum Islam terdapat perbedaan persepsi tentang harta bersama. Pertama, pendapat yang dikemukakan oleh Sajuti Thalib,SH dan Prof. Dr. Hazairin yang mengemukakan bahwa dalam Islam dikenal dengan adanya suatu harta bersama yaitu harta yang diperoleh oleh suami atau isteri karena usahanya, baik mereka bekerja bersama-sama atau hanya suami yang bekerja sedang isteri mengurus rumah tangga. Pendapat mereka ini berdasarkan pada Q.S An-Nissa

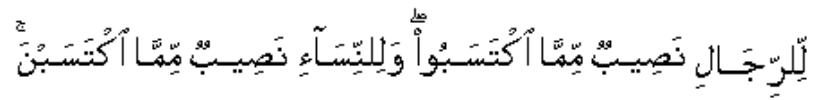

Terjemahannya :

“(Karena) bagi laki-laki ada bagian daripada apa yang mereka usahakan, dan bagi para perempuan (pun) ada bagian dari apa yang mereka usahakan."

Kedua, pendapat yang mengemukakan bahwa tidak ada harta bersama kecuali Syirqah (perjanjian) antara suami isteri. Menurut madzhab Syafi'i dalam Hukum Islam tidak dikenal adanya pencampuran harta kekayaan antara suami isteri dan isteri karena perkawinan. ${ }^{8}$ Jadi harta kekayaan isteri tetap menjadi milik isteri dan dikuasai sepenuhnya oleh isteri tersebut, demikian pula harta kekayaan suami tetap menjadi hak milik suami dan dikuasai sepenuhnya olehnya.

Dalam Islam sendiri syirqah diperbolehkan. Hal ini berdasarkan Hadits Nabi SAW, yang diriwayatkan oleh Abu Daud dan Hakim dari Abu Hurairah yang Artinya :

\footnotetext{
${ }^{6}$ Tim Penyusun Kamus Pembinaan dan Pengembangan Bahasa, Kamus Besar Bahasa Indonesia (Cet. IX, Jakarta; Balai Pustaka, 1997), h. 28.

${ }^{7}$ Departemen Agama RI Yayasan Penyelenggaraan Penerjemah Alqur'an, Alqur'an dan Terjemahan (Semarang: PT. Karya Toha Putra, 1971), h. 122.

${ }^{8}$ Mohd. Idris Ramulya, Hukum Perkawinan, Hukum Kawarisan, Hukum Acara Pengadilan Agama dan Zakat Menurut Hukum (Cet. II; Jakarta : Sinar Grafika, 2000), h.30.
} 
"Allah SWT, telah berfirman saya adalah orang ketiga dari dua orang yang berserikat. Selama seorang diantaranya tiada mengkhianati yang lain. Maka bila berkhianat salah seorang diantara keduanya, saya keluar dari perserikatan keduanya.",

Namun demikian, menurut hukum Islam dengan perkawinan menjadi sang isteri syarikatul rajuli filhayati yaitu kongsi sekutu seorang suami dalam melayani bahtera hidup, maka antara suami isteri dapat terjadi perkongsian tidak terbatas. ${ }^{10}$ Dalam hal ini maka harta kekayaan yang bersatu karena adanya syirkah seakanakan merupakan suatu harta kekayaan tambahan karena usaha bersama suami isteri secara perkawinan. Karena itu apabila kelak perjanjian perkawinan itu terputus karena perceraian atau talaq, maka harta syirkah itu dibagi antara suami isteri menurut pertimbangan sejauh mana usaha mereka (suami atau isteri) turut berusaha dalam syirkah.

Dalam perspektif fiqih Islam, sebagian ulama menganggap harta bersama sebagai harta syirkah yaitu syirkah kepemilikan (syirkah milik/syirkah amlak). Adapun yang dimaksud dengan syirkah kepemilikan yaitu :

Kepemilikan bersama atas suatu barang diantara dua orang atau lebih yang terjadi karena adanya salah satu sebab kepemilikan (seperti jual beli, hibah, wasiat dan waris), atau karena adanya pencampuran harta benda yang sulit untuk dipilahpilah dan dibedakan lagi. ${ }^{11}$

Secara garis besar dalam syari'at Islam, syirkah milik ini dibagi menjadi dua bagian, yaitu :

\section{Syirkah milikjabariah}

Syirkah milik jabariah ini adalah syirkah milik karena berdasarkan nashnash atau dalil naqli sehingga syirkah tersebut memiliki kekuatan hukum yang tepat.

\footnotetext{
${ }^{9}$ Abi Daud Sulaiman Ibn AlAsy’ats, Sunan Abi Daud, Jilik II (Cet. I; Beirut Dar al Kutub al Ilmiyah : 1996 M-1416 H), h. 462.

${ }^{10}$ Mohd. Idris Ramulyo, op. cit. h. 31

${ }^{11}$ LIhat, http://www.e syari'ahnet. diakses 26 Agustus 2004
} 


\section{Syirkah milik ikhtiyariyah (usaha)}

Syirkah milik ikhtiyariyah (usaha) ini adalah syirkah yang didirikan berdasarkan kehendak dan usaha dua orang yang berserikat. ${ }^{12}$

Adanya harta bersama dalam sebuah rumah tangga pada mulanya didasarkan atas ' $u r f f^{3}$ yang tidak memisahkan antara hak suami dan isteri. Hal inilah yang menjadi dasar hukum dari Pengadilan Agama Palangkaraya dalam mengadili perkara tentang harta bersama yang harus dibagi.

Karena begitu luas pengertian dari harta bersama ini sehingga dengan jelas akan tergambar ruang lingkup dari harta bersama. Adapun yang dimaksud dengan ruang lingkup harta bersama adalah untuk mencoba memberi penjelasan bagaimana cara menentukan apakah suatu harta termasuk atau tidak dalam objek harta bersama dalam suatu perkawinan. Berdasarkan ketentuan pada pasal $35 \mathrm{UU}$ No. 1 Tahun 1974, maka dapat diketahui bahwa dalam suatu perkawinan terdapat dua jenis harta kekayaan yaitu harta yang didapat sebelum perkawinan yang disebut harta bawaan dan harta yang diperoleh dalam perkawinan yang disebut dengan harta bersama. ${ }^{14}$ Kedua jenis harta kekayaan ini tidak bisa dicampur adukkan karena kedudukannya merupakan jenis yang berbeda yang sifatnya berdiri sendiri.

Dalam pasal 35 ayat I UU No. 1 tahun 1974 menegaskan bahwa harta beda yang diperoleh secara perkawinan menjadi harta bersama. Ini menunjukkkan bahwa segala sesuatu yang didapatkan selama perkawinan menjadi hak kedua suami isteri. Hal ini akan terbagi pada saat perkawinan ini putus demi hukum baik karena perceraian, kematian ataupun kaerna putusan Pengadilan Penegasan seperti ini juga dapat dilihat pada Putusan Mahkamah Agung RI No. 18 K/AG/1981. ${ }^{15}$ dalam putusan tersebut menegaskan bahwa hak dan kedudukan isteri adalah

${ }^{12}$ Surdarsona, Pokok-pokok Hukum Islam (Cet. I; Jakarta : Rineka Cipta, 1992), h. 450

${ }^{13}$ Urd adalah sesuatu yang sudah dikenal oleh orang dan telah menjadi tradisi mereka, baik berupa perkataan, atau perbuatan, atau keadaan meninggalkan. Lihat, Abdul Wahhab Khallaf, Ilmu Ushul Fiqh (Cet. I : Semarang : Bina Utama, 1994), h. 123.

${ }^{14}$ Ratna Lukito, Islamic Law and Adat Encounter The Experience of Indonesia (Jakarta: Logos, 2001), h. 109.

${ }^{15}$ Putusan-putusan Pengadilan Agama, Ioc.cit. 
seimbang dengan hak dan kewajiban suami dalam kehidupan bermasyarakat, artinya suami dan isteri berhak mendapat setengah bagian dari harta bersama.

Masalah harta bersama merupakan masalah vital yang sering disengketakan oleh pihak suami ataupun isteri pada saat terjadinya perceraian. Disinilah dibutuhkan kejelian dari pada hakim untuk dapat menilai, apakah harta tersebut merupakan harta bersama atau bukan. Dalam membuat patokan bahwa semua harta yang diperoleh selama perkawinan menjadi harta bersama, harus dikecualikan untuk harta yang diperoleh salah seorang suami atau isteri, yang disebabkan oleh warisan atau pemberian. Karena warisan atau pemberian yang diperoleh selama perkawinan semata-mata menjadi milik pribadi yang bersangkutan.

Setelah diketahui kapan terbentuknya suatu harta bersama, maka dipandang perlu untuk mengkaji tentang hal-hal apa sajakah yang termasuk dalam ruang lingkup harta bersama yang akan coba diuraikan melalui pendekatan yuridis.

1. Harta yang dibeli selama perkawinan

Patokan pertama untuk menentukan apakah sesuatu barang termasuk objek harta bersama atau bukan, ditentukan pada saat pembelian. Jadi apa saja yang dibeli selama perkawinan berlangsung otomatis menjadi harta bersama. Tidak menjadi soal siapa diantara suami isteri yang membelinya. Juga tidak menjadi masalah atas nama suami atau isteri harta itu terdaftar dan terletak dimanapun. Yang penting, apabila harta itu dibeli dalam perkawinan maka dengan sendirinya menurut hukum menjadi objek harta bersama.

Lain halnya jika uang pembeli barang berasal dari harta pribadi suami atau isteri. Jika uang pembelian barang berasal dari harta pribadi, maka barang yang dibeli tersebut tidak termasuk objek harta bersama. Harta yang seperti ini tetap menjadi milik bersangkutan.

2. Harta yang dibeli dan dibangun sesudah perceraian yang dibiayai dari harta bersama

Patokan berikut untuk menentukan sesuatu barang termasuk objek harta bersama, ditentukan oleh asal-usul uang biaya pembelian atau pembangunan 
barang yang bersangkutan, meskipun barang itu dibeli atau dibangun sesudah terjadinya perceraian. Misalnya jika suami isteri selama perkawinan memiliki simpanan yang sampai pada perceraian belum dibagi-bagikan. Kemudian jika salah satu pihak yang membeli rumah dari uang simpanan tersebut, maka rumah tersebut tetap menjadi harta bersama dan bukan merupakan harta milik isteri atau harta milik suami. Penerapan yang seperti ini harus dipegang secara utuh untuk menghindari manipulasi dan itikad buruk suami atau isteri. Karena dengan penerapan seperti ini, hukum tetap dapat menjangkau harta bersama sekalipun harta itu telah berubah bentuk menjadi barang lain. Sekiranya hukum tidak mampu menjangkau hal seperti itu, maka akan banyak terjadi manipulasi harta bersama sesaat setelah terjadinya perceraian, dengan pengharapan agar ia dapat menguasai sepenuhnya seluruh harta bersama. Maka untuk mengatasinya, asas kemutlakan harta bersama harus tetap melekat pada setiap barang dalam jenis dan bentuk apapun asal barang itu berasal dari harta bersama walaupun wujud barang yang baru itu diperoleh atau dibeli sesudah terjadinya perceraian.

3. Harta yang dapat dibuktikan diperoleh selama perkawinan

patokan ini sejalan dengan kaedah hukum harta bersama. Yakni semua harta yang diperoleh selama perkawinan dengan sendirinya menjadi harta bersama. Namun, dalam suatu sengketa harta bersama tidak semulus dan sesederhana itu. Pada umumnya, pada setiap perkara harta bersama, pihak yang digugat akan mengajukan bantahan bahwa harta yang digugat bukan merupakan harta bersama, tetapi merupakan harta pribadi. Hak kepemilikan seperti ini bisa berdasarkan atas hak kepemilikan, warisan ataupun karena hibah. Apabila terjadi hal seperti ini, maka untuk menentukan apakah barang tersebut merupakan objek harta bersama atau bukan, ditentukan oleh kammpuan dan keberhasilan dari penggugat untuk bisa membuktikan bahwa harta-harta tersebut benar-benar diperoleh selama dalam perkawinan.

4. Penghasilan harta bersama dan harta bawaan

Penghasilan yang berasal dari harta bersama dan dari harta pribadi suami isteri, maka otomatis akan menjadi objek harta bersama dan akan menambah jumlah dari harta bersama. Sekalipun hak dan kepemilikan harta pribadi mutlak 
berada di bawah kekuasaan pemiliknya. Namun harta pribadi tidak terlepas fungsinya dari kepentingan keluarga. Barang aslinya memang tidak boleh diganggu gugat, tetapi hasilnya akan menjadi objek harta bersama. Ketentuan ini, berlaku sepanjang suami isteri tidak menentukan lain dalam perjanjian perkawinan. Jika dalam perjanjian perkawinan tidak diatur mengenai hasil yang timbul dari harta pribadi, maka seluruh hasil yang diperoleh dari harta pribadi suami isteri menjadi objek harta bersama.

5. Segala Penghasilan Pribadi Suami Isteri

Menurut putusan Mahkamah Agung tanggal 11 Maret 1971 No. 454 K/SIP/1970 menegaskan bahwa segala penghasilan suami isteri baik dari keuntungan yang diperoleh dari perdagangan masing-masing ataupun hasil peroleh masing-masing sebagai pegawai jatuh menjadi harta bersama suami isteri. Jadi sepanjang mengenai penghasilan pribadi suami isteri, maka tidak terjadi pemisahan. Malahan dengan sendirinya terjadinya penggabungan kedalam harta bersama. Penggabungan penghasilan pribadi dengan sendirinya terjadi menurut hukum, sepanjang suami isteri tidak menentukan lain dalam perjanjian perkawinan. $^{16}$

Dengan demikian dapat diketahui bahwa harta bersama adalah harta yang diperoleh oleh suami isteri selama perkawinan dan menjadi hak kepemilikan berdua diantara suami isteri. Implikasinya, harta yang sudah dimiliki oelh suami atau isteri sebelum menikah karena warisan atau pemberian, semata-mata menjadi milik pribadi yang bersangkutan.

\section{Harta Bersama Dalam Komplikasi Hukum Islam}

Komplikasi Hukum Islam (KHI) adalah salah satu sumber hukum yang sering digunakan untuk oleh Majelis Hakim dalam memutuskan perkara-perkara Pengadilan Agama. KHI merupakan suatu wadah hukum yang berisi garis-garis hukum Islam yang berasal dari berbagai Kitab Fiqih yang ada. Keberadaan KHI pada satu segi memberikan kemudahan bagi hakim-hakim Pengadilan Agama

\footnotetext{
${ }^{16}$ M. Yahya Harahap, Keududkan Kewenangan dan Acara Peradilan Agama (Cet. I ; Jakarta : Garus Metropolitan Press, 1990), h. 303-306
} 
dalam menuelesaikan sengketa yang dihadapkan kepada mereka, sekalipun kewajiban untuk menemukan hukum yang hidup sesuai dengan rasa keadilan masyarakat tetap tidak terlepas dari fungsi mereka. ${ }^{17}$

Begitupun dalam penyelesaian sengketa harta bersama, KHI dijadikan salah satu rujukan oleh Majelis Hakim dalam pengambilan keputusan. Harta bersama dalam KHI disebut juga harta kekayaan dalam perkawinan yang diulas dalam 13 pasal yaitu pasal 85 - pasal 97.

Pengertian harta bersama menurut KHI dijelaskan pada pasal 1 huruf (f) yaitu harta yang diperoleh baik sendiri-sendiri atau bersama suami isteri selama dalam ikatan perkawinan berlangsung dengan tidak mempersoalkan terdaftar atas nama siapa. Adanya harta bersama dalam perkawinan itu tidak tertutup kemungkinan adanya harta milik masing-masing suami isteri (pasal $85 \mathrm{KHI}$ ). Harta bersama tersebut dapat berupa benda berwujud atau tidak berwujud (pasal 91 ayat 1). Harta bersama yang berwujud dapat meliputi benda tidak bergerak, benda bergerak dan surat-surat berharga (pasal 91 ayat 2), sedangkan harta bersama yang tidak berwujud dapat berupa hak dan kewajiban (pasal 91 ayat 3). Harta bersama dapat dijadikan sebagai barang jaminan oleh salah satu pihak atas persetujuan pihal lainnya (pasal 91 ayat 4). ${ }^{18}$

Berdasarkan pada pasal 86 ayat 1 KHI dijelaskan bahwa pada dasarnya tidak ada pencampuran antara harta suami dan harta isteri karena perkawinan. Untuk itulah dalam ayat berikutnya ditegaskan bahwa harga kekayaan yang dimiliki oleh suami atau isteri tetap menjadi milik mereka dan berhak untuk mengatasinya. Harta kekayaan yang seperti ini dapat berupa hadiah atau warisan yang diperoleh oleh masing-masing suami isteri sebelum atau pada saat perkawinan. Harta kekayaan yang semacam ini disebut dengan harta bawaan dan harta semacam ini tidak bisa dimasukkan dalam rung lingkup harta bersama kecuali suami isteri telah mengaturnya dalam perjanjian perkawinan.

\footnotetext{
${ }^{17}$ Departemen Agama RI Direktorat Jenderal Pembinaan Kelembagaan Agama Islam, Pedoman Penyuluhan Hukum (Jakarta; t.p. 1995), h. 25.

${ }^{18}$ Ibid., h. 197
} 
Perjanjian perkawinan adalah perjanjian yang dibuat dan diadakan sebelum perkawinan dilangsungkan. Biasanya perjanjian perkawinan dibuat untuk kepentingan perundangan hukum terhadap harta bawaan masing-masing suami ataupun isteri, meskipun undang-undang tidak mengatur tujuan perjanjian perkawinan dan apa yang dapat diperjanjikan, segalanya diserahkan pada para pihak. Sedangkan perjanjian perkawinan mulai berlaku sejak perkawinan dilangsungkan. ${ }^{19}$

Perjanjian perkawinan biasanya berisi tentang pemisahan harta kekayaan, yaitu antara harta bawaan dan harta bersama. Antara suami dan isteri tidak bisa mencampur adukkan kedua jenis hartakekayaan tersebut karena keduanya bersifat berdiri sendiri. Kalaupun terjadi perselisihan antara suami isteri mengenai harta kekayaan semacam ini maka para pihak yang merasa dirugikan dapat mengajukannya ke Pengadilan Agama, berdasarkan pada pasal 88 KHI.

Dengan demikian pihak dari suami atau isteri harus jelas mengetahui sejauh mana harta yang dikuasai oleh mereka yang termasuk dalam ruang lingkup harta bersama agar nantinya tidak terjadi kesimpang siuran dalam kepemilikan harta tersebut. Untuk itu pihak suami atau isteri tidak bisa mengubah status dari harta bersama, dalam artian menjual atau memindahkannya tanpa seijin dari salah satu pihak. ${ }^{20}$ Hal ini dimaksudkan agar masing-masing pihak dapat melakukan hal-hal yang berurusan dengan soal rumah tangga dengan penuh tanggung jawab. Tanpa adanya persetujuan tersebut, kemungkinan terjadinya penyimpangan besar sekali. Oleh karena itu kompilasi dalam pasal berikut, membicarakan pertanggungjawaban utang yang bersifat pribadi, bukan untuk kepentingan keluarga. Pada pasal 93 KHI menyatakan :

1). Pertanggungjawaban terhadap hutang suami atau isteri dibebankan pada hartanya masing-masing.

2). Pertanggungjawaban terhadap hutang yang dilakukan untuk kepentingan keluarga dibebankan kepada harta bersama.

\footnotetext{
${ }^{19}$ LIhat, http://www.Dunra-ibu.org.htm.perjanjian_pra_nikah.html., diakses tanggal 19 Agustus 2004

${ }^{20}$ LIhat pasal 92 Kompilasi Hukum Islam.
} 
3). Bila harta bersama tidak mencukupi, dibebankan kepada harta suami.

4). Bila harta suami tidak ada atau tidak mencukupi dibebankan kepada harta isteri. $^{21}$

Meskipun ketentuan pasal 93 tersebut seakan mengesankan adanya pemisahan antara harta kekayaan suami dan isteri, karena tidak ada penjelasan tentang kepada hutang suami atau isteri itu dilakukan, maka penafsiran yang dapat dilakukan daalah apabila hutang tersebut tidak ada sangkut pautnya dengan kepentingan keluarga. Namun sebaliknya, untuk menutupi kebutuhan rumah tangga, jika harta bersama tidak mencukupi maka diambil dari harta pribadi masing-masing suami atau isteri. Itupun apabila perkawinannya bersifat monogamy yang relatif kecil peluang terjadinya perselisihan diantara mereka, dibanding dalam perkawinan poligami.

Dalam kaitannya dengan perkawinan poligami, kompilasi mengaturnya dalam pasal 94 :

1) Harta bersama dari perkawinan seorang suami yang mempunyai isteri lebih dari seorang, masing-masing terpisah dan berdiri sendiri.

2) Pemilihan harta bersama dari perkawinan seorang suami mempunyai siteri lebih dari seorang sebagaimana tersebut ayat (1), dihitung pada saat berlangsungnya akad perkawinan yang kedua, ketiga atau keempat. ${ }^{22}$

Ketentuan ini dimaksudkan agar antara isteri pertama, kedua, ketiga atau keempat tidak terjadi perselisihan, termasuk mengantisipasi kemungkinan gugat warisan diantara masing-masing keluarga dan isteri-isteri tersebut. Akibat ketidakjelasan pemilihan harta bersama diantara isteri pertama dan kedua, sering menimbulkan sengketa waris, yang diajukan ke Pengadilan Agama.

Untuk itu dalam pasal 95 Kompilasi dibicarakan tentang tindakan-tindakan tertentu pada saat salah satu pihak melakukan perbuatan yang merugikan dan membahayakan harta bersama.

1) Dengan tidak mengurangi ketentuan pasal 24 ayat (2) huruf c Peraturan Pemerintah No. 9 tahun 1975 dan pasal 136 ayat (2), suami atau isteri dapat

\footnotetext{
${ }^{21}$ Pedoman Penyuluhan Hukum, Ioc, cit.

${ }^{22}$ Ibid., h. 198
} 
meminta Pengadilan Agama untuk meletakkan sita jaminan atas harta bersama tanpa adanya permohonan gugatan cerai, apabila salah satu melakukan perbuatan yang merugikan dan membahayakan harta bersama seperti judik, mabuk, boros dan sebagainya.

2) Selama masa sita dapat dilakukan penjualan atas harta bersama untuk kepentingan keluarga dengan izin Pengadilan Agama. ${ }^{23}$

Demikianlah hukum telah mengantisipasi segala bentuk penyimpangan yang mungkin akan terjadi terhadap harta bersama suami isteri. Untuk itulah bagi pihak yang merasa dirugikan dapat mengajukan permasalahan seperti ini ke Pengadilan Agama sehingga pada akhirnya berdasarkan putusan Pengadilan Agama akan membagi harta bersama tersebut secara adil kepada suami dan isteri berdasarkan ketentuan yang berlkau yaitu pasal $97 \mathrm{KHI}$, dimana janda atau duda cerai hidup masing-masing berhak seperdua dari harta bersama sepanjang tidak ditentukan lain dalam perjanjian perkawinan.

\section{Harta Bersama Dalam UU No. 1 Tahun 1974}

Seperti halnya Kompilasi Hukum Islam, UU No. 1 Tahun 1974 tentang perkawinan juga merupakan salah satu sumber rujukan para Hakim dalam menentukan suatu putusan. Perbedaannya terdapat pada pasal-pasal didalamnya, dimana dalam UU No. 1tahun 1974 membahas perihal harta bersama lebih sederhana, sehingga disinilah dibutuhkan kejelian daripada Hakim dalam mengkaji Undang-undang tersebut Harta bersama dalam UU No. 1 TAhun 1974

disebut dengan harta benda dalam perkawinan yang dibahas dalam 3 pasal yaitu pasal 35- pasal 37.

Untuk mengetahui bagaimana sistem pengaturan harta benda dalam perkawinan menurut UU No. 1 Tahun 1974, maka perlu diadakan pengkajian terhadap bunyi dan isi dari pasal-pasal yang ada.

Pada pasal 35 berbunyi :

1) Harta benda yang diperoleh selama perkawinan menjadiharta bersama.

\footnotetext{
${ }^{23}$ Ibid., h. 199
} 
2) Harta bersama dari masing-masing suami dan isteri dan harta benda yang diperoleh masing-masing sebagai hadiah atau warisan adalah dibawah penguasaan masing-masing si penerima para pihak tidak menentukan lain. ${ }^{24}$

Berdasarkan pada ketentuan pasal tersebut dapat diketahui bahwa pada hakekatnya dalam suatu perkawinan terdapat dua jenis harta kekayaan, yaitu harta yang diperoleh selama dalam perkawinan yang disebut dengan harta bersama, dan harta yang diperoleh oleh masing-masing suami dan isteri sebelum perkawinan atau pada saat perkawinan sebagai hadiah warisan yang lazim disebut dengan harta bawaan. Kedua jenis harta kekayaan ini tidak bisa dicampurkan karena keduanya merupakan jenis yang berbeda, terkecuali suami dan isteri telah menentukan lain dalam perjanjian perkawinan.

Jadi harta bersama adalah istilah untuk harta benda yang diperoleh oleh suami isteri selama perkawinan dan menjadi hak kepemilikan berdua diantara suami isteri. Adapun harta yang sudah dimiliki oleh suami atau isteri sebelum menikah, demikian pula mahar bagi isteri, juga warisan, wasiat dan hibah milik isteri atau suami tidak termasuk harta bersama.

Jadi, apabila isteri bekerja dan memperoleh harta, maka isteri punya hak penuh atas hartanya itu. Kecuali jika isteri menggunakan hartanya itu untuk keperluan keluarga dan dijadikan hak milik bersama (syirkah amlak). ${ }^{25}$

Adapun untuk harta bersama suami dan isteri ditentukan oleh faktor lamanya perkawinan. Artinya pada saat perkawinan berlangsung, maka otomatis segala harta benda yang diperoleh selama perkawinan tersebut menjadi harta bersama setelah putusnya perkawinan, baik karena perceraian, kematian ataupun atas putusan pengadilan, maka harta bersama tersebut dibagi secara adil kepada suami dan isteri dengan pembagian 50:50, atau setengah bagian untuk suami dan setengah bagian untuk isteri

Kemudian pada pasal 36 berbunyi :

\footnotetext{
${ }^{24}$ Departemen Agama RI Direktorat Jenderal Pembinaan Kelembagaan Agama Islam, Bahan Penyuluhan Hukum (Jakarta; t.p., 1996), h. 222.

${ }^{25}$ Lihat, http://www.hukumonline.com., diakses tanggal 19 Agustus 2004
} 
1) Mengenai harta bersama, suami isteri dapat bertindak atas persetujuan kedua belah pihak.

2) Mengenai harta bawaan masing-masing, suami dan isteri mempunyai hak sepenuhnya untuk melakukan perbuatan hukum mengenai harta bendanya. ${ }^{26}$

Pada penjelasan diatas telah disinggung tentang penggunaan harta bersama, dimana antara suami dan isteri mempunyai hak yang sama atas harta bersama. Hak ini berlaku juga bagi si isteri walaupun suami yang mencari nafkah sedangkan isteri hanya dirumah mengurus rumah tangga. Hal ini berdasarkan pemilihan antara suami isteri mempunyai hak dan kewajiban yang sama. Namun demikian, walaupun memiliki kesamaan hak terhadap harta bersama, baik suami ataupun isteri tidak bisa menyalahgunakan harta tersebut. Artinya segala sesuatu yang berhubungan dengan penggunaan harta bersama harus berdasarkan kesepakatan dan persetujuan dari kedua belah pihak. Maka dari itu, kedua belah pihak (suami dan isteri), mempunyai tanggung jawab untuk menjaga harta bersama tersebut, disamping perlu adanya rasa kepercayaan terhadap penggunaan kekayaan tersebut.

Pengecualian tersebut berlaku untuk harta yang diperoleh oleh masingmasing suami isteri sebelum perkawinan atau pada saat perkawinan karena ataupun warisan yang disebut dengan harta bawaan. Berdasarkan ketentuan pada pasal 36 ayat (2) UU No. 1 Tahun 1974 tentang perkawinan, maka harta pribadi dari suami atau isteri dikuasai sepenuhnya oleh mereka, dan mereka berhak melakukan perbuatan hukum berupa hibah, hadiah, sadaqah atau yang lainnya terhadap harta bendanya. Demi menggunakan dan mengelolah harta pribadi ini, para pihak tidak memerulkan persetujuan ataupun izin dari pihak yang lain. Namun harta tersebut bisa digunakan bersama atas dasar kesepakatan atau mungkin hal itu telah diatur dalam perjanjian pranikah. Kesepakatan seperti dalam Islam dikenal dengan istilah syrikah atau perkongsian dan hal ini dperbolehkan sepanjang tidak ada pihak yang merasa dirugikan.

Pasal terakhir dalam UU No. 1 Tahun 1974 yang membahas tentang harta bersama adalah pasal 37 yang menjelaskan bahwa bila perkawinan putus karena

${ }^{26}$ Bahan Penyuluhan Hukum , op. cit., h. 223 
perceraian, harta bersama diatur menurut hukumnya masing-masing. ${ }^{27}$ Pada pasal ini terkesan terlalu dangkal, sehingga diperlukan penjelasan dari undang-undang lain untuk memperkuat pasal tersebut.

Untuk itu pada penjelasan atas UU No. 1 Tahun 1974 menjelaskan bahwa yang dimaksud dengan "hukumnya" masing-masing ialah hukum agama, hukum adapt dan hukum-hukum lainnya. ${ }^{28}$ Maka dari itu jika suami dan isteri yang berselisih mempersoalkan masalah harta bersama dan mengajukannya ke Pengadilan Agama, maka ada ketentuan khusus yang diberlakukan untuk itu karena dalam hal terjadi sengketa kepemilikan dalam harta bersama, maka hal ini diselesaikan oleh Pengadilan Agama. ${ }^{29}$ Adapun ketentuan khusus yang dimaksud adalah UU No. 1 Tahun 1974. tentang perkawinan dan Kompilasi Hukum Islam. Kedua hukum acara inilah yang sering digunakan oleh Majelis Hakim sebagai tolak ukur penentuan amar putusan, sehingga putusan yang dihasilkan benar-benar memiliki asas keadilan dan bukan karena apriori.

\section{Kesimpulan}

Berdasarkan uraian di atas, dapatlah dirumuskan kesimpulannya sebagai berikut :

1. Pembagian harta bersama yang diterapkan dan mengacu kepada Kompilasi Hukum Islam khususnya pasal 97 menentukan bahwa janda atau duda yang cerai ,masing-masing mendapat seperdua dari harta bersama sepanjang tidak ditentukan lain dalam perjanjian perkawinan. Namun hal tersebut dapat berubah dengan adanya pertimbangan lain, misalnya pihak suami isteri bermaksud memberikan harta bersama tersebut kepada anakanak mereka.

2. Pembagian harta bersama menurut pasal 37 UU No. 1 tahun 1974, bila terjadi perceraian maka harta bersama diatur menurut hukumnya masing-

\footnotetext{
${ }^{27}$ Ibid

${ }^{28}$ Ibid., h. 243

${ }^{29}$ A. Mukti ARto, Praktek Perkara Perdata Pada Pengadilan Agama (Cet. IV : Yogyakarta Pustaka Pelajar, 2003), h. 249
} 
masing. Karena pasal ini terkesan terlalu dangkal, sehingga diperlukan penjelasan dan undang-undang lain untuk memperkuatnya

3. Pembagian harta bersama dapat dilakukan setelah adanya putusan Pengadilan yang telah memiliki kekuatan hukum tetap.

\section{Daftar Pustaka}

A, Soehardi, Mr. Pengantar Hukum Adat, Cet., III, Bandung : Vorrik Von Hoeve, t. th.

Arto, A. Mukti. Praktek Perkara Perdata Pada Pengadilan Agama, Cet. IV., Yogyakarta : Pustaka Pelajar, 2003

Departemen Agama RI, Yayasan Penyelenggara Penerjemah Alqur'an, Alqur'an dan Terjemahan, PT. Karya Toha Putra, 1971

Harahap, M. Yahaya. Kedudukan, Kewenangan dan Acara Peradilan Agama, Cet. I., Jakarta : Garuda Metropolitan Press, 1990.

Ibn Al Asy'ats, Abi Daud Sulaiman. Sunan Abi Daud, Jilid II., Cet. I., Bairut Dar al Kutub al Ilmiyah, 1996.

Khallaf, Abdul Wahhab. Ilmu Ushul Fiqh, Cet. I., Semarang : Bina Utama, 1994

Lukito, Ratna. Islamic Law And Encounter The Experience Of Indonesia, Jakarta : Logos, 2001.

Prodjodikoro, R.Wiryono. Hukum Perkawina di Indonesia, Cet. IX, Jakarta: Sumur Bandung, 1991

Ramulya, Mohd. Idris. Hukum Perkawinan, Hukum Kewarisan, Hukum Acara Peradilan Agama dan Zakat Menurut Hukum Islam, Cet, II, Jakarta : Sinar Grafika, 2000.

Sudarsono. Pokok-Pokok Hukum Islam, Cet. I., Jakarta : PT. Rineka Cipta,1992.

Tim Penyusun Kamus Pusat Pembinaan dan Pengembangan Bahasa, Kamus Besar Bahasa Indonesia, Cet., IX, Jakarta : Balai Pustaka, 1997. 